\section{OPEN ACCESS}

Edited by:

Jorge Monza,

Universidad de la República, Uruguay

Reviewed by:

Mahaveer P. Sharma,

ICAR Indian Institute of Soybean

Research, India

Bahar S. Razavi,

University of Kiel, Germany

*Correspondence:

Adnane Bargaz

adnane.bargaz@um6p.ma

Specialty section

This article was submitted to Plant-Soil Interactions,

a section of the journal

Frontiers in Agronomy

Received: 02 December 2020 Accepted: 17 February 2021

Published: 11 March 2021

Citation:

Janati W, Benmrid B, Elhaissoufi W, Zeroual Y, Nasielski J and Bargaz A (2021) Will Phosphate

Bio-Solubilization Stimulate Biological Nitrogen Fixation in Grain Legumes?

Front. Agron. 3:637196

doi: 10.3389/fagro.2021.637196

\title{
Will Phosphate Bio-Solubilization Stimulate Biological Nitrogen Fixation in Grain Legumes?
}

\begin{abstract}
Walid Janati ${ }^{1,2}$, Bouchra Benmrid ${ }^{1}$, Wissal Elhaissoufi ${ }^{1}$, Youssef Zeroual ${ }^{3}$, Joshua Nasielski ${ }^{4}$ and Adnane Bargaz ${ }^{1 *}$

${ }^{1}$ AgroBioSciences, Laboratory of Plant-Microbe Interactions, Mohammed VI Polytechnic University, Ben Guerir, Morocco, ${ }^{2}$ Department of Life Sciences, Laboratory of Functional Ecology and Environmental Engineering, Faculty of Sciences and Techniques, Sidi Mohamed Ben Abdellah University, Fez, Morocco, ${ }^{3}$ Situation Innovation, OCP Group, El Jadida, Morocco, ${ }^{4}$ Department of Plant Agriculture, University of Guelph, Guelph, ON, Canada
\end{abstract}

Biological nitrogen fixation (BNF) refers to a bacterially mediated process by which atmospheric $\mathrm{N}_{2}$ is reduced, either symbiotically or non-symbiotically, into ammonia $\left(\mathrm{NH}_{3}\right)$ in the presence of the enzyme complex nitrogenase. In $\mathrm{N}_{2}$-fixing grain legumes, BNF is often hampered under low phosphorus $(P)$ availability. The $P$ status of legumes, particularly nodules, as well as $\mathrm{P}$ availability in the rhizosphere, play a vital role in regulating BNF. Aside from increasing P availability via fertilization, other plant traits (i.e., extensive rooting system and their spatial distribution, hyper-nodulation, root exudates, rhizosphere acidification, and heterogeneity) contribute to greater $\mathrm{P}$ uptake and hence more effective BNF. The positive interaction between $P$ availability and BNF can be exploited through beneficial soil $P$ solubilizing microorganisms (PSM). These microorganisms can increase plant-available $\mathrm{P}$ by modifying either rhizosphere soil processes or promoting plant traits, which lead to increased $\mathrm{P}$ uptake by the production of plant growth-promoting substances, both of which could indirectly influence the efficiency of BNF in legumes. In this review, we report on the importance of microbial $P$ bio-solubilization as a pathway for improving BNF in grain legumes via PSM and $P$ solubilizing bacteria (PSB). Because BNF in legumes is a P-requiring agro-ecological process, the ability of soil PSB to synergize with the rhizobial strains is likely a key belowground process worth investigating for advanced research aiming to improve rhizosphere biological functions necessary for sustainable legume-based cropping systems.

Keywords: crops, inoculant, legumes, nodules, nitrogen fixation, rhizobia, rhizosphere, sustainability

\section{INTRODUCTION}

Legume crops play key roles both in food security and agro-ecosystems sustainability by providing several services at the food- and production-system levels (Stagnari et al., 2017). For instance, different legume crops varieties constitute a major source of plant-based food and feed and these crops can provide many other beneficial services (i.e., biological nitrogen $\left(\mathrm{N}_{2}\right)$ fixation, mitigation of greenhouse emission, suppression of weeds and plant diseases, etc.) (Sanginga et al., 2003; Stagnari et al., 2017; Mitran et al., 2018). In fact, legume crops play a key role in integrated soil fertility management owing to their capacity to fix atmospheric $\mathrm{N}_{2}$ in association with rhizobia, which can lead to increased soil fertility and decreased dependence on $\mathrm{N}$-fertilizers in low-input farming systems (Atienza and Rubiales, 2017; Vanlauwe et al., 2019). 
Traditionally, the application of organic and inorganic fertilizers to farm fields has been used to correct nutrient deficiencies and maintain nutrient balances (Li et al., 2020; Tewari et al., 2020), but negative environmental impacts could occur as a result of excessive and irrational nutrients application in agro-ecosystems that has received justified attention from stakeholders along the entire food value chain (Choudhury and Kennedy, 2005). There is increasing attention paid to the ability of purposefully selected soil microorganisms to enhance soil fertility through biological methods. The role of soil microorganisms in the cycling of $\mathrm{N}$ and $\mathrm{P}$ are wellknown, particularly the bacteria involved in BNF. But there is a growing understanding of the importance of other bacteria and fungi, either in the soil or in the plant (endophytes), for grain legume performance. Indeed, the exploitation and use of these soil microorganisms is a viable ecological strategy to reduce farmer dependence on inorganic fertilizers and enhance soil health (Zaidi et al., 2010). Enhancing biological nitrogen fixation (BNF) in grain legumes via soil microorganisms not directly involved in BNF could be a propitious option for increasing the supply of affordable and eco-friendly protein for human consumption while also improving the overall sustainability of cropping systems (Meena and Lal, 2018).

Some microorganisms at the soil root interface have the ability to establish a $\mathrm{N}_{2}$-fixing symbiosis with legumes based on nodule formation on roots or stems (Skorupska et al., 2010). Rhizobial symbiosis induces the formation of nodules in host plants' roots and fixes $\mathrm{N}_{2}$ to provide plants with ammonium$\mathrm{N}$ (Ahmad et al., 2014). In addition, rhizobia can also promote legume growth by other direct or indirect mechanisms (Zaidi et al., 2010). For instance, by improving water and nutrient uptake via tripartite symbiosis established by association with arbuscular mycorrhizal fungi (AMF) (Püschel et al., 2017). Another group of soil microorganisms namely $\mathrm{P}$ solubilizing microorganisms (PSM) can efficiently solubilize inorganic P forms, by transforming insoluble $\mathrm{P}$ into soluble and plantavailable forms. These microbial activities can enhance legume production while reducing reliance on fertilizer inputs (mainly $\mathrm{N}$ and P) (Ahmad et al., 2014). Therefore, for sustainable legume-based cropping systems, biological fertilization via the application of specific microbes should be promising for both crop productivity and economic-environmental sustainability.

The BNF is an energetically costly bioprocess that requires a significant investment in carbon and P (Püschel et al., 2017). Indeed the efficiency of BNF in grain legumes can be limited by $\mathrm{P}$ (Khan et al., 2007; Nasto et al., 2014; Aziz et al., 2016). According to Mitran et al. (2018), a number of studies reported a significant correlation between nodular $\mathrm{P}$ content and $\mathrm{N}_{2}$ fixation. In line with this, Attar et al. (2012) unveiled that P fertilization at $90 \mathrm{~kg}$ $\mathrm{ha}^{-1}$ enhanced the ability of common bean (Phaseolus vulgaris) to fix $\mathrm{N}_{2}$. In addition, it increased the release of hydrogen by roots which increased the plant-available form of $\mathrm{P}$ in the rhizosphere; which is the zone of soil surrounding the roots, rich in nutrients and contains a wide variety of microorganisms able to solubilize $\mathrm{P}$ (Vacheron et al., 2013); eventually leading to increased P uptake (Attar et al., 2012). In fact, adequate supply of $P$ to plants has been found to regulate several metabolic processes related to BNF, such as ammonium assimilation into amino acids and ureides (Mitran et al., 2018), as well as the synthesis of mitochondrial and symbiosome membranes for functional $\mathrm{N}_{2}$-fixing nodules (Bargaz et al., 2018; Si et al., 2019). Moreover, several authors claimed that the high demand of $\mathrm{P}$ during this biological process is also due to $\mathrm{N}_{2}$-fixing bacteria, whose $\mathrm{P}$ requirement was found to be higher compared to the non- $\mathrm{N}_{2}$-fixing bacteria (Nasto et al., 2017; Van Gerven et al., 2019; Fernández-Juárez et al., 2020). Altogether, nodule formation, nodule functioning, and the energy costs of BNF in legumes strongly depend on the $\mathrm{P}$ status in plants and nodule tissues, and inadequate $\mathrm{P}$ status will reduce potential $\mathrm{BNF}$ contribution to $\mathrm{N}$ uptake (Bargaz et al., 2018). Given all of the knowledge regarding the key role of $P$ in enhancing plant growth either by boosting the size of the root system (i.e., root hair density, lateral root growth, root surface area, and nodulation) or by stimulating the BNF process, soil PSM represents a promising strategy that could be adopted to increase plant-accessible forms of $\mathrm{P}$ to maintain soil health, fertility and agricultural sustainability (Wani et al., 2007; Qureshi et al., 2011; Bargaz et al., 2018; Elhaissoufi et al., 2020).

In the context of enhancing BNF in legumes, the present review summarizes available knowledge on the importance of PSM, with a focus on PSB, on BNF in grain legumes. We begin with an overview of the role of $\mathrm{P}$ in BNF. We then focus on recent research examining the ability of $\mathrm{P}$ bio-solubilization to enhance BNF. In addition, we hypothesized that rates of BNF could be sustainably enhanced in grain legumes via farmer use of PSM inoculation, given the importance of PSM as a biological component.

\section{IMPORTANCE OF P IN LEGUME BNF}

Biological $\mathrm{N}_{2}$ fixation is a symbiotic process (Lindström and Mousavi, 2020), during which plants provide shelter and carbon as an energy source to the symbiotic microorganisms in exchange for bacterially reduced nitrogenous compounds that can be readily assimilated by the host plant (Skorupska et al., 2010; Lazali et al., 2013; Lindström and Mousavi, 2020). Indeed, several published literatures reported that BNF supplies legume plants with an average of $80 \%$ of $\mathrm{N}$ needs (Skorupska et al., 2010; Santachiara et al., 2017), thus reducing the amount of mineral N needed especially in low inputs legume-based cropping systems (Hardarson and Atkins, 2003).

However, the establishment of this symbiotic relationship is shown to be affected by various biotic and abiotic factors among which is P deficiency (Mitran et al., 2018). It is of note that $\mathrm{P}$ is the second major macronutrient required for plant growth after $\mathrm{N}$, and it plays essential roles during all plant growth stages (Malhotra et al., 2018). Phosphorus is involved in the biosynthesis of major cellular constituents (i.e., nucleic acids, enzymes, phospholipids, ATP, and nucleotides), as well as in the control of vital processes such as photosynthesis, respiration, and energy generation (Balemi and Negisho, 2012; Sanz-Saez et al., 2017; Malhotra et al., 2018). While P deficiency reduces overall plant function and growth, its impact on bacterial BNF is one of the indirect functions played by $\mathrm{P}$ in legumes. Additionally, $\mathrm{P}$ 
controls the survival of soil microorganisms such as diazotrophic bacteria, as they require $\mathrm{P}$ for their growth; low levels of this nutrient may influence early-stage colonization processes and later nodules formation in legumes (Malhotra et al., 2018).

In fact, BNF as one of the main rhizosphere biological processes, is correlated with $\mathrm{P}$ availability wherein $\mathrm{P}$ deficiency strongly limits the activity of diazotrophic (i.e., $\mathrm{N}_{2}$-fixing bacteria), reduces the symbiotic partnership between plant host and rhizobia, as well as the $\mathrm{N}_{2}$-fixation process itself (Aziz et al., 2016; Martins et al., 2017; Sanz-Saez et al., 2017; Li et al., 2020; Tewari et al., 2020). Tewari et al. (2020) further highlighted the role of $\mathrm{P}$ as a structural element in controlling the BNF process. As an example, Tindwa et al. (2019) found that increased soil $\mathrm{P}$ availability in the presence of liming led to a subsequent increase in nodulation parameters such as, nodule number, nodule weight and volume, which in turn increased soybean (Glycine max) growth and the amount of fixed $\mathrm{N}_{2}$. Generally, P deficiency reduces nodule formation, development and function, reducing the supply of energy allocated to support nodule metabolic activity (Zaidi et al., 2010). Additionally, it was found that the $\mathrm{P}$ requirement for $\mathrm{N}_{2}$-fixing plants is higher than that of non- $\mathrm{N}_{2}$-fixing plants (Sanz-Saez et al., 2017). An increased $\mathrm{P}$ requirement of grain legumes is mainly due to the high P demand for BNF processes (Sanz-Saez et al., 2017; Mitran et al., 2018). In contrast, other authors claimed that the high demand of $\mathrm{P}$ during this biological process is due to the needs of $\mathrm{N}_{2}$-fixing bacteria, whose $\mathrm{P}$ requirement were found to be higher compared to non- $\mathrm{N}_{2-}$ fixers (Nasto et al., 2017; Van Gerven et al., 2019; Fernández-Juárez et al., 2020). Interestingly, the authors reported that the availability of various phospholipids (such as phosphatidylserine, phosphatidylcholine, and phosphatidylethanolamine) might play a role in nodulation and maintenance of legume-rhizobia symbiosis (Tewari et al., 2020). These compounds are essential for the establishment of a proper rhizobial membrane architecture that allows effective participation in BNF. In addition to its important role in BNF that takes place in the bacteroids, Mitran et al. (2018) reported a significant correlation between $\mathrm{P}$ concentration in the plant cell fraction of nodules and $\mathrm{N}_{2}$-fixation. This is because several metabolic processes that occur in plant cells notably, ammonium assimilation into amino acids and ureides were also found to be critically affected by P concentration (Batterman et al., 2013; Singh et al., 2013; Mitran et al., 2018). Li et al. (2020) found that increasing $\mathrm{P}$ content in soil and wheat (Triticum aestivum) plant tissues also enhanced total $\mathrm{N}$ and nitrogenase activity in plant shoots and roots along with nifH gene expression, supporting our understanding of the role of $\mathrm{P}$ in the enhancement of BNF (Wani et al., 2007).

The importance of adequate $\mathrm{P}$ availability to support BNF of grain legumes is receiving more attention (Olivera et al., 2004). A study by Taliman et al. (2019) found that $\mathrm{N}_{2}$ fixation and nodule biomass of soybean increased in response to high $\mathrm{P}$ fertilization. Co-application of biochar and P fertilizer to cowpea (Vigna unguiculata) improved soil properties encompassing cation exchange capacity, soil organic carbon, and total N, which correlated positively with nodules formation and subsequently $\mathrm{N}_{2}$ fixation capacity (Phares et al., 2020). Kyei-Boahen et al.
(2017) found that cowpea treated with rhizobia and P fertilizer showed greater $\mathrm{N}_{2}$ fixation as a result to increased number and biomass of nodules, ultimately leading to increased yield. Moreover, Sanz-Saez et al. (2017) reported that nodule and energy-generating metabolism depend strongly on $\mathrm{P}$ availability, as $\mathrm{P}$ deficiency reduces $\mathrm{P}$-nodules and $\mathrm{Pi}$-adenylates levels, resulting in decreased nitrogenase activity. Ultimately, this reduces the proportion of plant $\mathrm{N}$ derived from $\mathrm{BNF}$ (Sanz-Saez et al., 2017). To minimize the effects of $\mathrm{P}$ deficiency on BNF, nodules develop mechanisms to recycle and conserve internal $\mathrm{P}$ instead of acquiring external P (Vardien et al., 2014; Sanz-Saez et al., 2017). Indeed, leguminous plants tend to reallocate $P$ from both leaves and roots to their nodules, which in turn reduced aboveground processes such as photosynthesis, disturbing plant growth directly or indirectly (Sanz-Saez et al., 2017; Stevens et al., 2019).

\section{PHOSPHATE SOLUBILISING MICROORGANISMS STIMULATE BNF IN GRAIN LEGUMES}

The role of PSM such as bacteria and fungi in increasing soil $\mathrm{P}$ available fraction has been widely investigated by many researchers (Manzoor et al., 2017; Adhikari and Pandey, 2019; Faried et al., 2019). Phosphate solubilizing bacteria are the most known and studied microorganisms for their potential to solubilize $\mathrm{P}$. These microbes participate in bio-geochemical $\mathrm{P}$ cycling mainly through solubilization of inorganic forms of $\mathrm{P}$ and mineralization of organic ones (Manzoor et al., 2017; Abbasi and Manzoor, 2018). The microbial solubilization of insoluble $\mathrm{P}$ has been often attributed to organic acid excretion (i.e., lactic acid, succinic acid, acetic acid, fumaric acid, etc.) (Bhowmik and Das, 2018). In addition to their P bio-solubilization ability, PSM enhance plant growth through various mechanisms such as the release of important growth-promoting substances, the increase in soil availability of other micronutrients as well as the enhancement of $\mathrm{N}_{2}$ fixation efficiency (Zaidi et al., 2009; Rahman et al., 2017). Therefore, the application of these microbes to nutrient-deficient soils, where large amounts of nutrients are fixed in unavailable forms, could help farmers increase crop yield and financial returns via more rational use of $\mathrm{P}$ fertilizers inputs and an increase in BNF (Püschel et al., 2017). This fact was confirmed by Belimov et al. (1995) whose study consisted of using the ${ }^{15} \mathrm{~N}$ isotope dilution technique, and which revealed that a combination of $\mathrm{N}_{2}$-fixing (Azospirillum lipoferum) and P-solubilizing (Agrobacterium radiobacter) bacteria significantly increased $\mathrm{N}$ accumulation in barley (Hordeum vulgare). This corroborates with findings by Wani et al. (2007), who showed that triple inoculation of chickpea (Cicer arietinum) with a PSB (from genus Bacillus or Pseudomonas) and two $\mathrm{N}_{2}$ fixing Bacteria (Mesorhizobium cicero and Azotobacter chroococcum) increased soil fertility in terms of $\mathrm{P}$ and $\mathrm{N}$, enhanced nodulation, and stimulated chickpea growth compared to single inoculation. These positive effects were attributed to the synergies between PSM (particularly PSB) and $\mathrm{N}_{2}$ fixing bacteria, which resulted in enhanced BNF and increased nutrient use efficiency (Wani 
et al., 2007). Likewise, the combination of Rhizobium and a PSB strain (Bacillus megatherium), increased yield and seed quality of faba bean (Vicia faba) (Rugheim and Abdelgani, 2012) as well as yield, nodule biomass, shoot biomass and the $\mathrm{N}$ and $\mathrm{P}$ content of lablab bean (Lablab purpureus) shoots (Hassan and Abdelgan, 2009). These positive effects were concomitant with increased soil nutrients availability ( $\mathrm{N}$ and $\mathrm{P}$ ) and uptake in unfertilized soils.

Therefore, the synergy between soil PSM and rhizobial strains nodulating leguminous plants represent a key rhizosphere process that deserves to be thoroughly investigated to improve rhizosphere biological functions in grain legumes and enhance the sustainability of legume-based cropping systems. In line with this, several studies reported that soil application of PSM, including PSB, individually or in a consortium, increased plant growth through solubilization of insoluble $\mathrm{P}$ and subsequent increase in BNF (Batterman et al., 2013; Singh et al., 2013). In this context, Zaidi et al. (2010) found that PSB (genus Serratia) in association with $\mathrm{N}_{2}$-fixers (Mesorhizobium ciceri) and AMF (Glomus fasciculatum) could increase grain legume growth through a diverse range of mechanisms (i.e., enhanced BNF along with increased soil $\mathrm{N}$ and $\mathrm{P}$ availability), hence providing a promising solution to sustain low-input agricultural cropping systems. This finding was further confirmed by Ahmad et al. (2019) who showed that increased growth and nutritional status of mung bean (Vigna radiata) plants following their inoculation with PSB strains (Bacillus aryabhattai S10 and Bacillus subtilis ZM63) were concomitant with enhanced nodulation, measured in terms of nodules number and weight. A recent study by Li et al. (2020) showed that wheat co-inoculation with a diazotrophic bacterium (Paenibacillus beijingensis BJ18) and a PSB (Paenibacillus sp. B1) significantly increased plant growth as well as $\mathrm{P}$ and $\mathrm{N}$ content of both the plant (roots and shoots) and the soil. Elkoca et al. (2008) indicated a significant increase in nodulation, plant $\mathrm{N}$ content, yield, and seed protein content in chickpea in response to a mixed inoculation with Rhizobium, $\mathrm{N}_{2}$ fixing (Bacillus subtilis OSU142) and PSB (Bacillus megateriumM-3). Furthermore, Qureshi et al. (2011) reported an increase of mung bean root parameters (root mass, root length, nodule number, and nodule mass) in response to their inoculation with Rhizobium phaseoli and Bacillus megaterium, which subsequently increased uptake and use efficiency of $\mathrm{N}$ and $\mathrm{P}$. Likewise, when chickpea was inoculated with $\mathrm{N}_{2}$-fixing bacteria (Mesorhizobium ciceri), a phosphate solubilizing fungus (Penicillium WF6) and/or a PSB (Serratia T1), it resulted in an increase of $\mathrm{P}$ availability and uptake and also positively impacted BNF (Zaidi and Khan, 2007).

The synergies between legumes root, rhizobia, and AMF was also confirmed by Tajini et al. (2012) who carried out an experiment in which common bean plants treated with rhizobia (Rhizobium tropici) and inoculated with AMF (Glomus intraradices) showed enhanced BNF under low $\mathrm{P}$ conditions. This effect was likely mediated by improved $\mathrm{P}$ acquisition during legume-rhizobia-AMF symbiosis. According to SanzSaez et al. (2017), the increase in P uptake can be explained by the fact that AMF develops an important fungal hyphae network, which increases the root absorptive area and capacity.
Results from these cited studies provide strong evidence regarding the synergy between BNF and the use of PSB and PSM, either applied solely or in combined treatment. Adding PSB or PSM appears to increase BNF as well as $\mathrm{P}$ uptake, resulting in overall greater grain legume productivity. Optimizing PSM/PSB use in legume-based cropping systems may not only increase soil $\mathrm{P}$ availability, which would itself stimulate BNF, but may also enhance crop growth and yield through various mechanisms (i.e., production of plant growth regulators, siderophores, hydrogen cyanide, suppression of phytopathogens, etc.) that indirectly increase BNF as well. In light of this, Table 1 represents several published works of literature that have highlighted the role of microorganisms (including $\mathrm{PSB} / \mathrm{PSM}$ ) in maximizing BNF and increasing plant growth. However, further research investigations are needed in order to decipher the mechanisms by which these microbes communicate with their host plants, at the molecular and cellular levels so as to better understand the plant-microbe and microbemicrobe interactions.

\section{PHOSPHATE-SOLUBILISING BACTERIAL MECHANISMS FOR IMPROVED NODULATION AND BIOLOGICAL NITROGEN FIXATION}

Several researchers have advocated for direct farmer use of soil microbes, particularly PSM as bio-inoculants to make available nutrients previously fixed in unavailable forms, enhance BNF and overall soil health and fertility (Table 1) (Ahmad et al., 2014; Kumar, 2016). Phosphate solubilizing microorganisms applied to agricultural soils supply plants with $\mathrm{P}$ by converting insoluble forms of $\mathrm{P}$ into soluble ones in an environmental-friendly manner (Elkoca et al., 2008). The most studied PSM are PSB, among which pseudomonads, rhizobia, Azotobacter, bacilli were qualified as the most potent bacteria in terms of P bio-solubilization. Phosphate solubilizing bacteria may not only solubilize soil $\mathrm{P}$, but also increase the uptake and use efficiency of inorganic fertilizers and enhance crop production in different agro-ecological niches (Ahmad et al., 2014). Farmer use of PSB requires successful introduction into the microbial community of the rhizosphere, as it forms the symbiotic relationship with plant roots (Lindström and Mousavi, 2020). Indeed, microbes such as PSB possess multifarious mechanisms by which they contribute to plant growth promotion in general, and BNF in particular (Figure 1).

\section{Indirect Stimulation of BNF via Bacterially Produced Hormones}

One of the important mechanisms exerted by PSB is the production of plant growth regulators such as auxins, cytokinins, gibberellins, and ethylene (Anand et al., 2016). These molecules are known to promote root growth and make available previously inaccessible pools of $\mathrm{P}$ and this, in turn, contributes to fulfilling indirectly the energy costs of the BNF process (Zaidi et al., 2010). Indeed, several researchers found high concentrations 
TABLE 1 | Effects of phosphate solubilizing microorganisms on grain legumes growth, biological nitrogen fixation and nutrient uptake.

\begin{tabular}{|c|c|c|c|c|}
\hline & Bacterial species & Growth conditions & Effects on plants & References \\
\hline \multicolumn{5}{|c|}{ Legume species } \\
\hline Chickpea & $\begin{array}{l}\text { Rhizobium + P. striata or B. } \\
\text { Polymyxa }\end{array}$ & Greenhouse & $\begin{array}{l}\text { Increased the yield, nutrient uptake, and } \\
\text { nodulation also nitrogenase activity. }\end{array}$ & $\begin{array}{l}\text { Algawadi and Gaur, } \\
1988\end{array}$ \\
\hline Chickpea & $\begin{array}{l}\text { M. ciceri C-2/2 alone or with } \\
\text { P. + jessenii PS06 }\end{array}$ & Field conditions & $\begin{array}{l}\text { Enhanced symbiosis and produced higher } \\
\text { nodule mass, nodule number and shoot } \mathrm{N} \\
\text { content. }\end{array}$ & Valverde et al., 2007 \\
\hline Chickpea & $\begin{array}{l}\text { Rhizobium, } \mathrm{N}_{2} \text { fixing } \\
\text { Bacillus subtilis (OSU-142), } \\
\text { + PSB. megaterium (M-3) }\end{array}$ & $\begin{array}{l}\text { Controlled } \\
\text { conditions and field } \\
\text { conditions }\end{array}$ & $\begin{array}{l}\text { Increased plant height, shoot, root, and } \\
\text { nodule dry weight, N\%, chlorophyll } \\
\text { content, pod number, seed yield, total } \\
\text { biomass yield, and seed protein content. }\end{array}$ & Elkoca et al., 2008 \\
\hline $\begin{array}{l}\text { Common } \\
\text { Bean }\end{array}$ & $\begin{array}{l}\text { Paenibacillus polymyxa } \\
\text { (DSM 36) }+ \text { R. tropici } \\
\text { (CIAT899) }\end{array}$ & Greenhouse & $\begin{array}{l}\text { Increase leghemoglobin concentrations, } \\
\text { nitrogenase activity and } \mathrm{N}_{2} \text { fixation } \\
\text { efficiency. }\end{array}$ & Figueiredo et al., 2008 \\
\hline $\begin{array}{l}\text { Common } \\
\text { Bean }\end{array}$ & Azospirillum and Rhizobium & $\begin{array}{l}\text { Greenhouse and } \\
\text { farm }\end{array}$ & $\begin{array}{l}\text { Increased the amount of fixed nitrogen } \\
\text { and the yield. }\end{array}$ & Roseline et al., 2008 \\
\hline Pigeon pea & $\begin{array}{l}\text { Bacillus sp. and Azospirillum } \\
s p+\text { Rhizobium }\end{array}$ & $\begin{array}{l}\text { Controlled } \\
\text { conditions }\end{array}$ & Enhance nodulation and $\mathrm{N}_{2}$ fixation. & Rajendran et al., 2008 \\
\hline Pea & $\begin{array}{l}\text { B. simplex } 30 \mathrm{~N}-5 \text { or } B \text {. } \\
\text { subtilis } 30 \mathrm{VD}-1+R \text {. } \\
\text { leguminosarum bv. viciae } \\
128 \mathrm{C} 53\end{array}$ & Greenhouse & $\begin{array}{l}\text { Nodules were larger, clustered, and } \\
\text { developed more highly branched vascular } \\
\text { bundles, supporting nitrogen fixation. }\end{array}$ & Schwartz et al., 2013 \\
\hline \multicolumn{5}{|c|}{ Non-legume species } \\
\hline Sugarcane & Azospirillum & Greenhouse & Increased N content of leaves. & $\begin{array}{l}\text { Muthukumrasamy } \\
\text { et al., } 1999\end{array}$ \\
\hline Wheat & $\begin{array}{l}\text { Azospirillum brasilense and } \\
\text { Azospirillum lipoferum with } \\
\text { Zoogloea Ky1 }\end{array}$ & $\begin{array}{l}\text { Controlled } \\
\text { conditions }\end{array}$ & Contributed $7-12 \%$ of plant $\mathrm{N}$ by BNF. & Malik et al., 2002 \\
\hline Maize & $\begin{array}{l}\text { Klebsiella sp. Br1, K. } \\
\text { pneumoniae } \mathrm{Fr} 1 \text {, andB. } \\
\text { pumilus S1r1 }\end{array}$ & Greenhouse & $\begin{array}{l}\text { Ability to BNF and increased the total N } \\
\text { content. }\end{array}$ & Kuan et al., 2016 \\
\hline
\end{tabular}

of auxin in root nodules, which confirms the vital role of this hormone in nodule formation and functioning (Mathesius et al., 1998; Van Noorden et al., 2006). Rao (2014) reported that co-inoculation of AMF (Glomus fasciculatum) along with rhizobia significantly improved nodulation, BNF, shoot $\mathrm{N}$ and $\mathrm{P}$ content and yield of soybean. Likewise, Qureshi et al. (2012) reported that co-inoculation of mash bean (Vigna mungo L.) with Rhizobium and a P solubilizing strain (Bacillus sp.) increased plant growth not only due to $\mathrm{P}$ solubilizing and $\mathrm{N}_{2}$-fixation abilities but also due to their capacity to produce auxin. These authors reported that microbial auxin altered endogenous hormonal level, which in turn increased root length, root biomass, number of nodule and number of infection sites, which further resulted in increased plant growth. This corroborates with findings by Ahmad et al. (2019) who showed that co-inoculation of mung bean plants with Bacillus aryabhattai S10 and Bacillus subtilis ZM63 increased nodulation, plant growth, and the nutritional status 


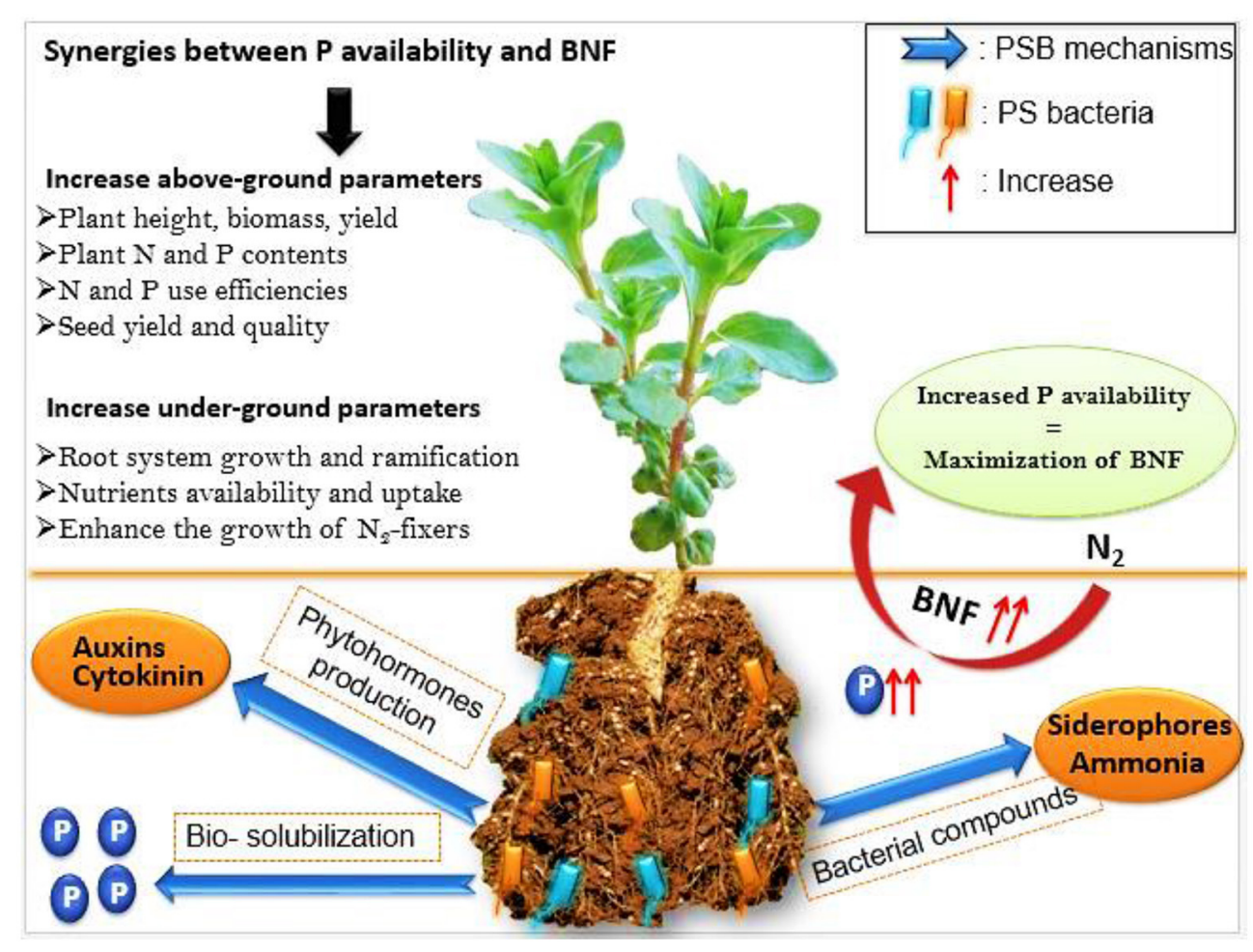

FIGURE 1 | Interactions between PSB and legumes nodulated roots and their effects on nutrients availability and the overall plant growth parameters.

of the tested plants. The increment of nodulation parameters was likely attributed to the improved formation of nodules through the increased surface area of rhizobial infection during nodulation. Mixed-inoculation of soybean plants with Rhizobium, Enterobacter and PSM (not identified) increased plant biomass, weight and length of pods as well as root nodulation parameters. The latter being a consequence of increased production of auxin and gibberellin by the combined action of the tested microbes, subsequently leading to increased cell division and elongation. Eventually, increasing the overall plant growth, yield and productivity (Yasmeen and Bano, 2014).

Similarly, Figueiredo et al. (2008) stated that cytokinin produced by a PSB strain (Paenibacillus polymyxa DSM 36) could influence BNF in common bean plants, most likely through the stimulation of rhizobial growth, nodule development and the number of infections in roots (Figure 1). This corroborates with findings by Elkoca et al. (2008) who revealed that production of plant growth regulators by Bacillus subtilis (OSU-142) and Bacillus megaterium (M-3) increased root system growth which in turn increased the number of infection sites. Moreover, Kannapiran and Ramkumar (2011) reported that black gram (Phaseolus mungo) N status was enhanced following inoculation with several bacteria amongst two PSB strains (Pseudomonas aeruginosa and Bacillus $s p$ ). In fact, these positive effects were attributed to several metabolites produced by the tested bacteria, such as siderophores, HCN, auxin and ammonia.

\section{Phosphorus Bio-Availability as a Key Mechanism for Enhanced BNF}

According to several studies, $\mathrm{P}$ solubilization may be one of the main mechanisms by which PSB enhances the BNF (Wani et al., 2007; Püschel et al., 2017; Bargaz et al., 2018; Bhowmik and Das, 2018). Common and soybean plants treated with biofertilizer (a consortium of three PSB: Pseudomonas sp., Burkholderia sp., and Enterobacter sp.) combined with rock phosphate in soil with low fertility found to increase the soil and plants $\mathrm{P}$ content, providing favourable conditions to plant nodulation which in turn increased the efficiency of BNF (Fankem et al., 2015). Stajković et al. (2011) shown that bioavailable P has a positive influence on the legume-rhizobia symbiosis. These authors observed positive effects of bio-available $\mathrm{P}$ on nodulation and nitrogenase activity in common bean plants following their inoculation with Rhizobium phaseoli and Pseudomonas sp. (a P solubilizing bacteria). Additionally, Korir et al. (2017) revealed that mixed-inoculation of common bean plants with Rhizobium, Bacillus megaterium and Paenibacillus polymyxa enhanced shoot and root weight of the plants as well as nodule number and biomass. These authors stated that nodulation parameters were enhanced as a result of increased $\mathrm{P}$ availability, which is known to stimulate growth and expansion of roots, thus offering to the rhizobial strains more active sites for nodulation. In addition, a field experiment conducted by Dutta and Bandyopadhyay (2009), showed that co-inoculation of chickpea plants with $\mathrm{P}$ fertilizer at $26.2 \mathrm{~kg} / \mathrm{ha}$ along with $\mathrm{P}$ 
bio-fertilizers [Rhizobium and phosphobacterin (Pseudomonas striata)] enhanced symbiotic properties measured in terms of number and weight of nodules, leghemoglobin content, and nitrogenase activity, which ultimately enhanced plant growth and yield. In fact, these beneficial effects were particularly attributed to the positive effects of increased $\mathrm{P}$ availability on the bacteria rather than the host plant. According to Jat and Ahlawat (2004), $\mathrm{P}$ availability controls the motility and migration of the bacterial cells, which is a prerequisite for the host infection and thus for the nodules development and the overall BNF process.

Additionally, it is reported that the PSB when applied with other plant growth-promoting rhizobacteria (PGPR) could reduce $\mathrm{P}$ fertilizer application by $50 \%$ without any significant reduction in crop yields or $\mathrm{BNF}$, allowing more rational use of Mahanta et al. (2018). Therefore, the exploitation of PSM as bio-fertilizers holds great promise for sustaining crop production. Ahmad et al. (2014) suggest that PSB can interact positively with other microorganisms such as $\mathrm{N}_{2}$-fixers and AMF, eventually leading to increased legume growth through a range of mechanisms. In fact, the beneficial influence of AMF has been attributed to the increase in auxin and abscisic acid contents in roots, shoots, and nodules, which increased the size and activity of nodules, enhanced micronutrient uptake from the soil, and increasing protection against biotic and abiotic stresses (Ahmad et al., 2014; Rao, 2014).

Although there are numerous reports highlighting interactions between PSB, $\mathrm{N}_{2}$-fixing bacteria, and AMF, the underlying mechanisms behind these associations are not yet fully understood.

Thus, further studies are needed to deepen our understanding about these microorganisms' beneficial interactions. Additionally, based on the above described knowledge regarding the beneficial effect of PSB in fostering below-ground bioprocesses, these microbial strains should be evaluated in extensive field trials to evaluate their potential to be used as biofertilizers. However, based on the cited studies, the mechanisms by which the bioavailable $\mathrm{P}$ affects nodulation and BNF is not yet deciphered. Therefore, further studied aiming to understand profoundly, at the molecular and cellular scale, the effects of the bio-available $\mathrm{P}$ on BNF are needed.

\section{NITROGEN-FIXING BACTERIA AND PHOSPHATE SOLUBILIZING MICROORGANISMS: KEY AGRO-ECOLOGICAL ENGINEERING DRIVERS GEARING TOWARD SUSTAINABLE AGRICULTURE}

Ecological engineering is a system-based approach aims to restore, optimize or even enhance the normal functioning of an ecosystem (Mitsch, 2012). This approach was first adopted in China in 1978 (Mitsch et al., 1993) and has been applied to address sustainability concerns in many other ecosystems, including agro-ecosystems (Mitsch and Jørgensen, 2003; Power, 2010). This strategy relies on the use of internal ecological processes, not only to restore the normal function of a given ecosystem but also to prevent further disruption of other ecosystems (Hengsdijk and Van Ittersum, 2003). Soil supports the growth of different microbial populations, many of which are involved in providing different categories of soil ecosystem services, directly or indirectly, such as nutrient cycling, organic matter degradation, contaminants removal, supporting soil fertility, resistance to different stresses, production of bioactive compounds that stimulate plants growth and other beneficial effects (Barrios, 2007; Wagg et al., 2014; Saccá et al., 2017). These functions are mostly the consequence of mutualistic associations established between plants and root-associated microorganisms (Martin et al., 2017). Given recent scientific advances regarding the beneficial effects provided by these microbes, it is evident that $\mathrm{N}_{2}$-fixing bacteria and PSB/PSM play a key role in providing agro-ecosystem services, which ultimately lead to maintain, sustain, and enhance agro-ecosystems services (Bender et al., 2016).

Phosphorus and $\mathrm{N}$ play an important role in agro-ecosystems nutrient balances, as they are often limiting factors for soil fertility in low-input systems (Sharma et al., 2013). Soil microorganisms such as $\mathrm{N}_{2}$-fixing symbionts and PSB/PSM contribute directly to the restoration of soil fertility by cycling nutrients such as $\mathrm{N}$ and $\mathrm{P}$, ultimately leading to enhanced soil fertility and the maintenance of adequate plant growth (Bender et al., 2016). This process involves both biotic and abiotic factors with PSM considered among the key biotic factors that influence the cycling of $\mathrm{P}$ (i.e., sorption-desorption, dissolution-precipitation, and mineralization-immobilization) (Sharma et al., 2013) and $\mathrm{N}$ (i.e., $\mathrm{N}_{2}$-fixation into plant-available ammonium; nitrification of ammonium into nitrogen oxides; or denitrification of $\mathrm{NO}_{3}$ into $\mathrm{N}_{2} \mathrm{O}$ and $\mathrm{N}_{2}$ ) within the soil (Bender et al., 2016).

As described previously, PSB releases insoluble P (Rfaki et al., 2020), whereas $\mathrm{N}_{2}$-fixing symbionts reduce $\mathrm{N}_{2}$ into ammonia either symbiotically or non-symbiotically (Bhattacharjee et al., 2008). Therefore, these microbes could act as promising ecological engineers contributing to more sustainable agriculture. $\mathrm{N}_{2}$-fixing bacteria (symbiotic and non-symbiotic) have been widely studied in the last decade because of their role in supplying plants with $\mathrm{N}$ (Oberson et al., 2013). Kuan et al. (2016) noted that almost $80 \%$ of the $\mathrm{N}$ available to plants comes from the symbiotic group, including Rhizobium which infects plants to form nodules. Whereas the nonsymbiotic group consists of free-living microorganisms, such as, Bacillus, Azotobacter, Azospirillum, and Herbaspirillum (Arfarita et al., 2019), which contributes to approximately $5-10 \%$ of the biological $\mathrm{N}$ inputs into the soil $\mathrm{N}$ cycle (Son, 2001). In a two-year field study, Amirnia et al. (2019) demonstrated that $\mathrm{N}_{2}$-fixing bacterial strain belonging to the genus of Azotobacter in combination with AMF (Glomus intraradices) enhanced soil fertility and plant growth under rainfed conditions, as application resulted in higher biomass yield, seed yield and seed protein of lentil (Lens culinaris Medik), thus the authors suggested that this bio-fertilizer has great potential in an arid and semi-arid area, in order to fulfill plant nitrogenous requirements and productivity under rainfed conditions. Moreover, Raklami et al. (2019) stated that coinoculation of faba bean plant with a consortium of PGPR 
(Acinetobacter sp. and Rahnella aquatilis) rhizobia (Ensifer meliloti (RhOF4) and Ensifer meliloti (RhOF155) and AMF (Glomus sp. Sclerocystis sp. Acaulospora sp.), PGPR-RhizobiaAMF increased soil fertility in terms of $\mathrm{N}$ and $\mathrm{P}$, subsequently leading to increased plant growth.

As discussed above, AMF were shown to be involved in managing agro-ecosystems functioning. These fungi form a tripartite symbiosis with plants and $\mathrm{N}_{2}$-fixing bacteria. Musyoka et al. (2020) revealed that tripartite symbiosis involving mung bean (Vigna radiata L.) plants, Bradyrhizobium, and an AMFconsortium (Rhizophagus irregularis, Funneliformis mosseae, Glomus etunicatum, Glomus aggregatum) enhanced $\mathrm{N}_{2}$ fixation, nutrients acquisition, and overall plant growth. Intercropping systems based on mixing legumes and non-legumes could also take advantage of this type of symbiosis. For instance, a study by Meng et al. (2015) highlighted the contribution of AMF and rhizobium in improving yield advantages of maize/soybean intercropping systems. In this experiment, the bacteria increased nodulation and $\mathrm{N}_{2}$-fixation, while the AMF, through its hyphae, increased the degree of contact between soybean and maize which resulted in more $\mathrm{N}$ transfer to non-legume crops (Meng et al., 2015).

Besides their capacity in increasing, restoring, and/or maintaining soil fertility (Xavier and Germida, 2003), these microbes contribute to providing various ecosystem services in order to enhance and maintain agro-ecosystems productivity, stability, and sustainability (Paudyal et al., 2007; Ismaiel et al., 2014; Ullah et al., 2017). Disease suppression is considered as one of the microbial potentials to be involved indirectly in plant protection. This effect was illustrated by Negi et al. (2019) who showed that bio-priming of French bean (Phaseolus vulgaris cv. Contender) seed with Rhizobium (B1), Trichoderma viride and a PGPR strain enhanced plant growth, pod yield, seed yield, seed quality, seed vigour and reduced incidence of diseases such as root rot and angular leaf spot under field conditions. Moreover, growth of auxin plant under water stress conditions was found to be improved as a response to Bradyrhizobium, and AMFconsortium (Rhizophagus irregularis, Funneliformis mosseae, Glomus etunicatum, and Glomus aggregatum) inoculation (Musyoka et al., 2020).

Faba bean growth in alkaline conditions was found to be increased following their inoculation with Rhizobium Legumiosarum and AMF (Acaulospora laevis, Glomus geosporum, Glomus mosseae, and Scutellospora armeniaca) (Abd-Alla et al., 2014). Plant growth increase was likely attributed to the increased number and biomass of nodules, nitrogenase activity, leghemoglobin, and mycorrhizal colonization. In fact, BNF is enhanced due to AMF-mediated increases in plant uptake of nutrients such as $\mathrm{P}, \mathrm{Fe}$, and $\mathrm{K}$ (among others) (Abd-Alla et al., 2014). Under saline conditions, inoculation of chickpea plant with Rhizobium, AMF and Stenotrophomonas maltophilia resulted in enhanced plant growth, which is most likely due to increased nutrient availability, including P (Abd-Alla et al., 2019).

Additionally, soil contaminants (organic waste, xenobiotics) are one of the most common problems that threaten soil health and plant growth (Saccá et al., 2017). However, Ismaiel et al. (2014) revealed that plants inoculation with $\mathrm{N}_{2}$-fixing Rhizobium leguminosarum bv. viceae and AMF (Glomus mosseae, Gigaspora sp., and Acaulospora sp) alleviated heavy metals toxicity and enhanced plant growth simultaneously. Taken all together, these microorganisms either used solely or in mixed inoculation showed promising results both on plant nutrient uptake, growth and protection. The use of PSM in legume-based cropping systems in an integrated manner, along with other sources of nutrients such as manure and inorganic fertilizers, show promise as a cost-effective strategy to increase nutrient use efficiency, BNF and overall yield and grain quality, particularly in low-input systems. However, the full contribution of soil biota including $\mathrm{N}_{2}$-fixing bacteria, PSB, and PSM to agroecosystem functioning in a range of climates, soil types, and cropping systems has yet to be deciphered. Additional research addressing the functional capacity of PSM, including their ability to synergize BNF in the field is required to unlock the potential. Agricultural field- experiments are needed to further understand the agronomic relevance of PSM, as well as the functional mechanisms underlying the plant-microbe and microbe-microbe interactions.

\section{CONCLUSION}

Nitrogen and $\mathrm{P}$ are two essential macronutrients required for plant growth and development. While many farmers rely on inorganic sources of $\mathrm{P}$ to avoid nutrient deficiencies, nontrivial amounts of these fertilizers are fixed in the soil or lost through different mechanisms, thus remain unavailable for plant uptake. In legume-based cropping systems, $\mathrm{P}$ deficiencies can also lead to $\mathrm{N}$ deficiency and reduced crop yields. Based on the studies cited in this review, bio-fertilization using rhizosphere microorganisms such as PSM/PSB and/or $\mathrm{N}_{2}$ fixing bacteria showed promising effects on BNF in particular and overall plant growth in general. Targeted application of specific soil microorganisms thus presents a propitious costeffective management strategy that could increase optimization of $\mathrm{N}$ and $\mathrm{P}$ fertilizer eco-efficiency in an environmentallyfriendly manner. However, there is still a need to conduct further research investigations in order to improve PSM responses under variable agro-climatic conditions. Field trials conducted under agriculturally relevant conditions, measuring crop-level responses to PSM, are required for validation. Additionally, the mechanisms underlying the rhizobial-PSM-plant interactions as well as the microbemicrobe interaction are not yet fully deciphered. Therefore, further research should focus on improving knowledge regarding the functional mechanisms behind these microbial interactions, taking into account those interactions with crop species, so that compatible organisms can be determined and used as effective bio-fertilizers in sustainable crop production systems.

\section{AUTHOR CONTRIBUTIONS}

All authors listed have made a substantial, direct and intellectual contribution to the work, and approved it for publication. 


\section{ACKNOWLEDGMENTS}

This review is carried out within the framework of MSc theses of both WJ and BB hosted at the Plant-Microbe

\section{REFERENCES}

Abbasi, K. M., and Manzoor, M. (2018). Biosolubilization of phosphorus from rock phosphate and other $\mathrm{P}$ fertilizers in response to phosphate solubilizing bacteria and poultry manure in a silt loam calcareous soil. J. Plant Nutr. Soil Sci. 181, 345-356. doi: 10.1002/jpln.2018 00012

Abd-Alla, M. H., El-Enany, A. W. E., Nafady, N. A., Khalaf, D. M., and Morsy, F. M. (2014). Synergistic interaction of Rhizobium leguminosarum bv. viciae and arbuscular mycorrhizal fungi as a plant growth promoting biofertilizers for faba bean (Vicia faba L.) in alkaline soil. Microbiol. Res. 169, 49-58. doi: 10.1016/j.micres.2013.07.007

Abd-Alla, M. H., Nafady, N. A., Bashandy, S. R., and Hassan, A. A. (2019). Mitigation of effect of salt stress on the nodulation, nitrogen fixation and growth of chickpea (Cicer arietinum L.) by triple microbial inoculation. Rhizosphere 10:100148. doi: 10.1016/j.rhisph.2019.100148

Adhikari, P., and Pandey, A. (2019). Phosphate solubilization potential of endophytic fungi isolated from Taxus wallichiana Zucc. Roots Rhizosphere 9, 2-9. doi: 10.1016/j.rhisph.2018.11.002

Ahmad, E., Zaidi, A., and Khan, M. S. (2014). "Response of PSM inoculation to certain legumes and cereal crops," in Phosphate Solubilizing Microorganisms, ed. M. S. Khan, A. Zaidi and J. Musarrat (Cham: Springer), 175-205. doi: 10.1007/978-3-319-08216-5_8

Ahmad, M., Adil, Z., Hussain, A., Mumtaz, M. Z., Nafees, M., Ahmad, I., et al. (2019). Potential of phosphate solubilizing bacillus strains for improving growth and nutrient uptake in mungbean and maize crops. Pak. J. Agri. Sci. 56, 283-289. doi: 10.21162/PAKJAS/19.7285

Algawadi, A. R., and Gaur, A. C. (1988). Associative effect of Rhizobium and phosphate-solubilizing bacteria on the yield and nutrient uptake uptake of chickpea. Plant Soil 105, 241-246. doi: 10.1007/BF02376788

Amirnia, R., Ghiyasi, M., Moghaddam, S. S., Rahimi, A., Damalas, C. A., and Heydarzadeh, S. (2019). Nitrogen-fixing soil bacteria plus mycorrhizal fungi improve seed yield and quality traits of lentil (Lens culinaris Medic). J. Soil Sci. Plant Nutr. 19, 592-602. doi: 10.1007/s42729-019-00058-3

Anand, K., Kumari, B., and Mallick, M. A. (2016). Phosphate solubilizing microbes: an effective and alternative approach as biofertilizers. Int. J. Pharm. Pharm. Sci. $8,37-40$

Arfarita, N., Muhibuddin, A., and Imai, T. (2019). Exploration of indigenous free nitrogen-fixing bacteria from rhizosphere of Vigna radiata for agricultural land treatment. J. Degrade. Min. Land Manage. 6:1617. doi: $10.15243 / \mathrm{jdmlm} .2019 .062 .1617$

Atienza, S. G., and Rubiales, D. (2017). Legumes in sustainable agriculture. Crop Past. Sci. 68, i-ii. doi: 10.1071/CPv68n11_FO

Attar, H. A., Blavet, D., Selim, E. M., Abdelhamid, M. T., and Drevon, J. J. (2012). Relationship between phosphorus status and nitrogen fixation by common beans (Phaseolus vulgaris L.) under drip irrigation. Int. J. Environ. Sci. Technol. 9, 1-13. doi: 10.1007/s13762-011-0001-y

Aziz, A., Ahiabor, B., Opoku, A., and Abaidoo, R. (2016). Contributions of rhizobium inoculants and phosphorus fertilizer to biological nitrogen fixation, growth and grain yield of three soybean varieties on a fluvic luvisol. Am. J. Exp. Agric. 10, 1-11. doi: 10.9734/AJEA/2016/20072

Bai, Y. M., Zhou, X. M., and Smith, D. L. (2003). Enhanced soybean plant growth resulting from coinoculation of Bacillus strains with Bradyrhizobium japonicum. Crop Sci. 43, 1774-1781. doi: 10.2135/cropsci2003.1774

Balemi, T., and Negisho, K. (2012). Management of soil phosphorus and plant adaptation mechanisms to phosphorus stress for sustainable crop production: a review. J. Soil Sci. Plant Nutr. 12, 547-561. doi: $10.4067 /$ S0718-95162012005000015

Bargaz, A., Lyamlouli, K., Chtouki, M., Zeroual, Y., and Dhiba, D. (2018). Soil microbial resources for improving fertilizers efficiency in an
Interactions Laboratory at Mohammed VI Polytechnic University. This work is part of a research project (AS17 2019-2022) financially supported by OCP Group at Mohammed VI Polytechnic University. integrated plant nutrient management system. Front. Microbiol. 9:1606. doi: $10.3389 /$ fmicb.2018.01606

Barrios, E. (2007). Soil biota, ecosystem services and land productivity. Ecol. Econ. 64, 269-285. doi: 10.1016/j.ecolecon.2007.03.004

Batterman, S. A., Wurzburger, N., and Hedin, L. O. (2013). Nitrogen and phosphorus interact to control tropical symbiotic N2 fixation: a test in Inga punctate. J. Ecol. 101, 1400-1408. doi: 10.1111/1365-2745.12138

Belimov, A. A., Kojemiakov, A. P., and Chuvarliyeva, C. V. (1995). Interaction between barley and mixed cultures of nitrogen fixing and phosphatesolubilizing bacteria. Plant Soil. 173, 29-37. doi: 10.1007/BF00155515

Bender, S. F., Wagg, C., and van der Heijden, M. G. A. (2016). An underground revolution: biodiversity and soil ecological engineering for agricultural sustainability. Trends Ecol. Evol. 31, 440-452. doi: 10.1016/j.tree.2016.02.016

Bhattacharjee, R. B., Singh, A., and Mukhopadhyay, S. N. (2008). Use of nitrogenfixing bacteria as biofertiliser for non-legumes: prospects and challenges. Appl. Microbiol. Biotechnol. 80, 199-209. doi: 10.1007/s00253-008-1567-2

Bhowmik, S. N., and Das, A. (2018). "Biofertilizers: a sustainable approach for pulse production," in Legumes for Soil Health and Sustainable Management, eds R. S. Meena, A. Das, G. Singh and Y. Rattan Lal (Singapore: Springer), 445-485. doi: 10.1007/978-981-13-0253-4_14

Choudhury, A. T. M. A., and Kennedy, I. R. (2005). Nitrogen fertilizer losses from rice soils and control of environmental pollution problems. Commun. Soil Sci. Plant Anal. 36, 1625-1639. doi: 10.1081/CSS-200059104

Downey, J., and van Kessel, C. (1990). Dual inoculation of Pisum sativum with Rhizobium leguminosarum and Penicillium bilaji. Biol. Fertil. Soils 10, 194-196. doi: 10.1007/BF00336135

Dutta, D., and Bandyopadhyay, P. (2009). Performance of chickpea (Cicer arietinum L.) to application of phosphorus and bio-fertilizer in laterite soil. Arch. Agron. Soil Sci. 55, 147-155. doi: 10.1080/03650340802398864

Elhaissoufi, W., Khourchi, S., Ibnyasser, A., Ghoulam, C., Rchiad, Z., Zeroual, Y., et al. (2020). Phosphate solubilizing rhizobacteria could have a stronger influence on wheat root traits and aboveground physiology than Rhizosphere $\mathrm{P}$ solubilization. Front. Plant Sci. 11, 1-15. doi: 10.3389/fpls.2020.00979

Elkoca, E., Kantar, F., and Sahin, F. (2008). Influence of nitrogen fixing and phosphorus solubilizing bacteria on the nodulation, plant growth, and yield of chickpea. J. Plant Nutr. 31, 157-171. doi: 10.1080/01904160701742097

Fankem, H., Tchuisseu Tchakounte, G. V., Ngo Nkot, L., Mafokoua, H. L., Tchouomo, D. D., Simo, C., et al. (2015). Common bean (Phaseolus vulgaris L.) and soya bean (Glycine max) growth and nodulation as influenced by rock phosphate solubilising bacteria under pot grown conditions. Int. J. Agric. Policy Res. 3, 242-250. doi: 10.15739/IJAPR.046

Faried, A. S. M., Mohamed, H. M., El-Dsouky, M. M., and El-Rewainy, H. M. (2019). Isolation and characterization of phosphate solubilizing actinomycetes from rhizosphere soil. AJAS 49, 125-137. doi: 10.21608/ajas.2018.28381

Fernández-Juárez, V., Bennasar-Figueras, A., Sureda-Gomila, A., Ramis-Munar, G., and Agawin, N. S. R. (2020). Differential effects of varying concentrations of phosphorus, iron, and nitrogen in $\mathrm{N}_{2}$-fixing cyanobacteria. Front. Microbiol. 11, 1-19. doi: 10.3389/fmicb.2020.541558

Figueiredo, M. V. B., Martinez, C. R., Burity, H. A., and Chanway, C. P. (2008) Plant growth-promoting rhizobacteria for improving nodulation and nitrogen fixation in the common bean (Phaseolus vulgaris L.). World J. Microbiol. Biotechnol. 24, 1187-1193. doi: 10.1007/s11274-007-9591-4

Hardarson, G., and Atkins, C. (2003). Optimising biological $\mathrm{N}_{2}$ fixation by legumes in farming systems. Plant Soil. 252, 41-54. doi: 10.1023/A:1024103818971

Hassan, M. A., and Abdelgan, M. E. (2009). Effect of microbial biofertilization on nodulation, nitrogen and phosphorus content and forage yield of lablab bean (Lablab purpureus L.). Am.-Eurasian J. Sustain. Agric. 3, 829-835.

Hengsdijk, H., and Van Ittersum, M. K. (2003). Formalizing agro-ecological engineering for future-oriented land use studies. Eur. J. Agron. 19, 549-562. doi: 10.1016/S1161-0301(03)00002-9 
Ismaiel, A. A., Hegazy, H. S., and Azb, M. A. (2014). Physiological response of Vicia faba L. to inoculation with Rhizobium and arbuscular mycorrhizal fungi: comparative study for irrigation with Nile water and wastewater. Aust. J. Crop Sci. 8, 781-790.

Jat, R. S., and Ahlawat, I. P. S. (2004). Effect of vermicompost, biofertilizer and phosphorus on growth, yield and nutrient uptake by gram (Cicer arietinum) and their residual effect on fodder maize (Zea mays). Indian J. Agric. Sci. 74, 359-361.

Kannapiran, E., and Ramkumar, V. S. (2011). Inoculation effect of nitrogenfixing and phosphate-solubilizing bacteria to promote growth of black gram (Phaseolus mungo Roxb ; Eng). Ann. Biological Res. 2, 615-621.

Khan, M. S., Zaidi, A., and Wani, P. A. (2007). Role of phosphate-solubilizing microorganisms in sustainable agriculture - a review. Agron. Sustain. Dev. 27, 29-43. doi: 10.1051/agro:2006011

Korir, H., Mungai, N. W., Thuita, M., Hamba, Y., and Masso, C. (2017). Coinoculation effect of rhizobia and plant growth promoting rhizobacteria on common bean growth in a low phosphorus soil. Front. Plant Sci. 8, 141. doi: $10.3389 /$ fpls.2017.00141

Kuan, K. B., Othman, R., Rahim, K. A., and Shamsuddin, Z. H. (2016). Plant growth-promoting rhizobacteria inoculation to enhance vegetative growth, nitrogen fixation and nitrogen remobilisation of maize under greenhouse conditions. PLoS ONE 11, 1-19. doi: 10.1371/journal.pone.0152478

Kumar, A. (2016). Phosphate solubilizing bacteria in agriculture biotechnology: diversity, mechanism and their role in plant growth and crop yield. Int. J. Adv. Res. 4, 116-124. doi: 10.21474/IJAR01/111

Kyei-Boahen, S., Savala, C. E. N., Chikoye, D., and Abaidoo, R. (2017). Growth and yield responses of cowpea to inoculation and phosphorus fertilization in different environments. Front. Plant Sci. 8, 1-13. doi: 10.3389/fpls.2017.00646

Lazali, M., Zaman-Allah, M., Amenc, L., Ounane, G., Abadie, J., and Drevon, J. J. (2013). A phytase gene is overexpressed in root nodules cortex of Phaseolus vulgaris-rhizobia symbiosis under phosphorus deficiency. Planta 238, 317-324. doi: 10.1007/s00425-013-1893-1

Li, Y., Li, Q., Guan, G., and Chen, S. (2020). Phosphate solubilizing bacteria stimulate wheat rhizosphere and endosphere biological nitrogen fixation by improving phosphorus content. PeerJ. 8:e9062. doi: 10.7717/peerj.9062

Lindström, K., and Mousavi, S. A. (2020). Effectiveness of nitrogen fixation in rhizobia. Microb. Biotechnol. 13, 1314-1335. doi: 10.1111/1751-7915.13517

Mahanta, D., Rai, R. K., Dhar, S., Varghese, E., Raja, A., and Purakayastha, T. J. (2018). Modification of root properties with phosphate solubilizing bacteria and arbuscular mycorrhiza to reduce rock phosphate application in soybean-wheat cropping system. Ecol. Eng. 111, 31-43. doi: 10.1016/j.ecoleng.2017.11.008

Malhotra, H., Vandana, S. S., and Pande, R. (2018). "Phosphorus nutrition: plant growth in response to deficiency and excess," in Plant Nutrients and Abiotic Stress Tolerance, eds. M. Hasanuzzaman, M. Fujita, H. Nahar, K. Oku and B. Hawrylak-Nowak (Singapore: Springer) 171-190. doi: 10.1007/978-981-10-9044-8_7

Malik, K. A., Mirza, M. S., Hassan, U., Mehnaz, S., Rasul, G., Haurat, J., et al. (2002). "The role of plant associated beneficial bacteria in rice-wheat cropping system," in Biofertilisers in Action. Rural Industries Research and Development Corporation, eds I. R. Kennedy A. T. M. A. Chaudhry (Canberra), 73-83.

Manzoor, M., Abbasi, M. K., and Sultan, T. (2017). Isolation of phosphate solubilizing bacteria from maize rhizosphere and their potential for rock phosphate solubilization-mineralization and plant growth promotion. Geomicrobiol. J. 34, 81-95. doi: 10.1080/01490451.2016.1146373

Martin, F. M., Uroz, S., and Barker, D. G. (2017). Ancestral alliances: plant mutualistic symbioses with fungi and bacteria. Science 356:6340. doi: 10.1126/science.aad4501

Martins, D., Macovei, A., Leonetti, P., Balestrazzi, A., and Araújo, S. (2017). "The infuence of phosphate defciency on legume symbiotic N2 fixation," in Legume Nitrogen Fixation in Soils with Low Phosphorus Availability, eds S. Sulieman and L. S. P. Tran (Cham: Springer), 41-76. doi: 10.1007/978-3-319-55729-8_3

Mathesius, U., Schlaman, H. R. M., Spaink, H. P., Sautter, C., Rolfe, B. G., and Djordjevic, M. A. (1998). Auxin transport inhibition precedes root nodule formation in white clover roots and is regulated by flavonoids and derivatives of chitin oligosaccharides. Plant J. 14, 23-34 doi: 10.1046/j.1365-313X.1998.00090.x
Meena, R. S., and Lal, R. (2018). "Legumes and sustainable use of soils," in Legumes for Soil Health and Sustainable Management, eds R. S. Meena, A. Das, G. S. Yadav and R. Lal (Singapore: Springer), 1-31. doi: 10.1007/978-981-13-0253-4_1

Meng, L., Zhang, A., Wang, F., Han, X., Wang, D., and Li, S. (2015). Arbuscular mycorrhizal fungi and rhizobium facilitate nitrogen uptake and transfer in soybean/maize intercropping system. Front. Plant Sci. 6, 1-10. doi: 10.3389/fpls.2015.00339

Mitran, T., Meena, R. S., Lal, R., Layek, J., Kumar, S., and Datta, R. (2018). Role of soil phosphorus on legume production. Legum. Soil Heal. Sustain. Manag. 487-510. doi: 10.1007/978-981-13-0253-4_15

Mitsch, W. J. (2012). What is ecological engineering? Ecol. Eng. 45, 5-12. doi: 10.1016/j.ecoleng.2012.04.013

Mitsch, W. J., and Jørgensen, S. E. (2003). Ecological engineering: a field whose time has come. Ecol. Eng. 20, 363-377. doi: 10.1016/j.ecoleng.2003.05.001

Mitsch, W. J., Yan, J., and Cronk, J. K. (1993). Ecological engineeringcontrasting experiences in China with the West. Ecol. Eng. 2, 177-191. doi: 10.1016/0925-8574(93)90013-6

Musyoka, D. M., Njeru, E. M., Nyamwange, M. M., and Maingi, J. M. (2020). Arbuscular mycorrhizal fungi and Bradyrhizobium co-inoculation enhances nitrogen fixation and growth of green grams (Vigna radiata L.) under water stress. J. Plant Nutr. 43, 1036-1047. doi: 10.1080/01904167.2020.1711940

Muthukumrasamy, R., Revathi, G., and Lakshminarasimhan, C. (1999). Diazotrophic association in sugar can cultivation in South India. Trop Agri. 76, 171-178.

Nasto, M. K., Alvarez-Clare, S., Lekberg, Y., Sullivan, B. W., Townsend, A. R., and Cleveland, C. C. (2014). Interactions among nitrogen fixation and soil phosphorus acquisition strategies in lowland tropical rain forests. Ecol. Lett. 17, 1282-1289. doi: 10.1111/ele.12335

Nasto, M. K., Osborne, B. B., Lekberg, Y., Asner, G. P., Balzotti, C. S., Porder, S., et al. (2017). Nutrient acquisition, soil phosphorus partitioning andcompetition among trees in a lowland tropical rain forest. New Phytol. 214, 1506-1517. doi: 10.1111/nph.14494

Negi, S., Bharat, N. K., and Kumar, M. (2019). Effect of seed biopriming with indigenous PGPR, Rhizobia and Trichoderma sp. on growth, seed yield and incidence of diseases in French bean (Phaseolus vulgaris L.). Legum. Res. 47, 288-295. doi: 10.18805/LR-4135

Oberson, A., Frossard, E., Bühlmann, C., Mayer, J., Mäder, P., and Lüscher, A. (2013). Nitrogen fixation and transfer in grass-clover leys under organic and conventional cropping systems. Plant Soil 371, 237-255. doi: $10.1007 /$ s11104-013-1666-4

Olivera, M., Tejera, N., Iribarne, C., Ocana, A., and Lluch, C. (2004). Growth, nitrogen fixation and ammonium assimilation in common bean (Phaseolus vulgaris): effect of phosphorus. Physiol. Plant 121, 498-505. doi: 10.1111/j.0031-9317.2004.00355.x

Paudyal, S., Aryal, R. R., Chauhan, S., and Maheshwari, D. (2007). Effect of heavy metals on growth of rhizobium strains and symbiotic efficiency of two species of tropical legumes. Sci. World 5, 27-32. doi: 10.3126/sw.v5i5.2652

Phares, C. A., Atiah, K., Frimpong, K. A., Danquah, A., Asare, A. T., and Aggor-Woananu, S. (2020). Application of biochar and inorganic phosphorus fertilizer influenced rhizosphere soil characteristics, nodule formation and phytoconstituents of cowpea grown on tropical soil. Heliyon. Heliyon. 6:e05255. doi: 10.1016/j.heliyon.2020.e05255

Power, A. G. (2010). Ecosystem services and agriculture: tradeoffs and synergies. Philos. Trans. R Soc. B Biol. Sci. 365, 2959-2971. doi: 10.1098/rstb.2010.0143

Püschel, D., Janoušková, M., Voríšková, A., Gryndlerová, H., Vosátka, M., and Jansa, J. (2017). Arbuscular mycorrhiza stimulates biological nitrogen fixation in two Medicago spp. through improved phosphorus acquisition. Front. Plant Sci. 8, 1-12. doi: 10.3389/fpls.2017.00390

Qureshi, M. A., Iqbal, A., Akhtar, N., Shakir, M. A., and Khan, A. (2012). Coinoculation of phosphate solubilizing bacteria and rhizobia in the presence of L-tryptophan for the promotion of mash bean (Vigna mungo L.). Soil Environ. 31, 47-54.

Qureshi, M. A., Shakir, M. A., Iqbal, A., Akhtar, N., and Khan, A. (2011). Coinoculation of phosphate solubilizing bacteria and rhizobia for improving growth and yield of mungbean (Vigna radiata L.). J. Anim. Plant Sci. 21, 491-497. 
Rahman, C. H., Ahcene, B., Miloud, B., and Rachid, D. (2017). Screening and characterization of plant growth promoting traits of phosphate. Malays. J. Microbiol. 13, 124-131.

Rajendran, G., Sing, F., Desai, A. J., and Archana, G. (2008). Enhanced growth and nodulation of pigeon pea by co-inoculation of Bacillus strains with Rhizobium spp. Bioresour. Technol. 99, 544-550. doi: 10.1016/j.biortech.2007. 06.057

Raklami, A., Bechtaoui, N., Tahiri, A. I., Anli, M., Meddich, A., and Oufdou, K. (2019). Use of rhizobacteria and mycorrhizae consortium in the open field as a strategy for improving crop nutrition, productivity and soil fertility. Front. Microbiol. 10:1106. doi: 10.3389/fmicb.2019. 01106

Rao, D. L. N. (2014). Recent advances in biological nitrogen fixation in agricultural systems. Proc. Indian Natl. Sci. Acad. 80, 359-378. doi: 10.16943/ptinsa/2014/v80i2/55114

Rfaki, A., Zennouhi, O., Aliyat, F. Z., Nassiri, L., and Ibijbijen, J. (2020). Isolation, selection and characterization of root-associated rock phosphate solubilizing bacteria in Moroccan Wheat (Triticum aestivum L.). Geomicrobiol. J. 37, 230-241. doi: 10.1080/01490451.2019.1694106

Roseline, R., Lara, R., Sarah, S., German, H., Aurelio, G., Jorge, R., et al. (2008). Effect of Rhizobium-Azospirillum coinoculation on nitrogen fixation and yield of two contrasting Phaseolus vulgaris L. genotypes cultivated across different environments in Cuba. Plant Soil. 302, 149-161. doi: 10.1007/s11104-008-9606-4

Rugheim, A. M. E., and Abdelgani, M. E. (2012). Effects of microbial and chemical fertilization on yield and seed quality of faba bean (Vicia faba). Int. Food Res. J. $19,417-422$

Saccá, M. L., Caracciolo, A. B., and Lenola, M. D. (2017). "Ecosystem services provided by soil microorganisms", in Soil Biological Communities and Ecosystem Resilience, eds. M. Lukac, P. Grenni and M. Gamboni (Cham: Springer), 9-24. doi: 10.1007/978-3-319-63336-7_2

Sanginga, N., Dashiell, K. E., Diels, J., Vanlauwe, B., Lyasse, O., Carsky, R. J., et al. (2003). Sustainable resource management coupled to resilient germplasm to provide new intensive cereal-grain-legume-livestock systems in the dry savanna. Agric. Ecosyst. Environ. 100, 305-314. doi: 10.1016/S0167-8809(03)00188-9

Santachiara, G., Borrás, L., Salvagiotti, F., Gerde, J. A., and Rotundo, J. L. (2017). Relative importance of biological nitrogen fixation and mineral uptake in high yielding soybean cultivars. Plant Soil. 418, 191-203. doi: 10.1007/s11104-017-3279-9

Sanz-Saez, A., Morales, F., Arrese-Igor, C., and Aranjuelo, I. (2017). "P Defciency: A Major Limiting Factor for Rhizobial Symbiosis," in Legume Nitrogen Fixation in Soils with Low Phosphorus Availability, eds S. Sulieman and L. S. P. Tran (Cham: Springer), 21-40. doi: 10.1007/978-3-319-55729-8_2

Schwartz, A. R., Ortiz, I., Maymon, M., Herbold, C. W., Fujishige, N. A., Vijanderan, J. A., et al. (2013). Bacillus simplex-a little known PGPB with antifungal activity-alters pea legume root architecture and nodule morphology when co-inoculated with Rhizobium leguminosarum Bv. Viciae. Agrononmy 3, 595-620. doi: 10.3390/agronomy3040595

Sharma, S. B., Sayyed R. Z., Trivedi, M. H., and Gobi, T. A. (2013). Phosphate solubilizing microbes: sustainable approach for managing phosphorus deficiency in agricultural soils. Springerplus. 2:587. doi: 10.1186/2193-1801-2-587

Si, Z., Yang, Q., Liang, R., Chen, L., Chen, D., and Li, Y. (2019). Digalactosyldiacylglycerol synthase gene MTDGD1 plays an essential role in nodule development and nitrogen fixation. Mol. Plant-Microbe Interact. 32, 1196-1209. doi: 10.1094/MPMI-11-18-0322-R

Singh, O., Gupta, M., Mittal, V., Kiran, S., Nayyar, H., Gulati, A., et al. (2013). Novel phosphate solubilizing bacteria 'Pantoea cypripedii PS1' along with Enterobacter aerogenes PS16 and Rhizobium Cicero enhance the growth of chickpea (Cicer arietinum L.). Plant Growth Regul. 73, 79-89. doi: 10.1007/s10725-013-9869-5

Skorupska, A., Wielbo, J., Kidaj, D., and Marek-Kozaczuk, M. (2010). "Enhancing rhizobium-legume symbiosis using signaling factors", in Microbes for Legume Improvement, eds Khan, A. Zaidi and J. Musarrat (Vienna: Springer), 27-54. doi: 10.1007/978-3-211-99753-6_2

Son, Y. (2001). Non-symbiotic nitrogen fixation in forest ecosystems. Ecol. Res. 16, 183-196. doi: 10.1046/j.1440-1703.2001.00385.x
Stagnari, F., Maggio, A., Galieni, A., and Pisante, M. (2017). Multiple benefits of legumes for agriculture sustainability: an overview. Chem. Biol. Technol. Agric. 4, 1-13. doi: 10.1186/s40538-016-0085-1

Stajković, O., Delic, D., Josic, D., Kuzmanovic, D., Rasulic, N., and KnezevicVukcevic, J. (2011). Improvement of common bean growth by co-inoculation with Rhizobium and plant growth-promoting bacteria. Rom. Biotechnol. Lett. 16, 5919-5926.

Stevens, G. G., Pérez-Fernández, M. A., Morcillo, R. J. L., Kleinert, A., Hills, P., Brand, D. J., et al. (2019). Roots and nodules response differently to p starvation in the mediterranean-type legume virgilia divaricata. Front. Plant Sci. 10:73. doi: 10.3389 /fpls.2019.00073

Subramanian, P., Kim, K., Krishnamoorthy, R., Sundaram, S., and Tongmin, S. (2015). Endophytic bacteria improve nodule function and plant nitrogen in soybean on co-inoculation with Bradyrhizobium japonicum MN110. Plant Growth Regul. 76, 327-332. doi: 10.1007/s10725-014-9993-x

Tajini, F., Trabelsi, M., and Drevon, J. J. (2012). Combined inoculation with Glomus intraradices and Rhizobium tropici CIAT899 increases phosphorus use efficiency for symbiotic nitrogen fixation in common bean (Phaseolus vulgaris L.). Saudi J. Biol. Sci. 19, 157-163. doi: 10.1016/j.sjbs.2011.11.003

Taliman, N. A., Dong, Q., Echigo, K., Raboy, V., and Saneoka, H. (2019). Plants effect of phosphorus fertilization on the growth, photosynthesis, nitrogen fixation, mineral accumulation, seed yield, and seed quality of a soybean low-phytate line. Plants 8:119. doi: 10.3390/plants8050119

Tewari, S., Pooniya, V., and Sharma, S. (2020). Next generation bioformulation prepared by amalgamating Bradyrhizobium, cell free culture supernatant, and exopolysaccharides enhances the indigenous rhizospheric rhizobial population, nodulation, and productivity of pigeon pea. Appl. Soil Ecol. 147:103363. doi: 10.1016/j.apsoil.2019.103363

Tindwa, H. J., Kachiguma, A., and Mrema, J. P. (2019). Incubation of soil with agricultural lime and phosphorus enhances biological nitrogen fixation and yield of soybean (Glycine max (L.) merrill) in an ultisol. J. Cent. Eur. Agric. 20, 938-952. doi: 10.5513/JCEA01/20.3.2118

Ullah, S., Khan, M. Y., Asghar, H. N., Akhtar, M. J., and Zahir, Z. A. (2017). Differential response of single and co-inoculation of Rhizobium leguminosarum and Mesorhizobium ciceri for inducing water deficit stress tolerance in wheat. Ann. Microbiol. 67, 739-749. doi: 10.1007/s13213-017-1302-2

Vacheron, J., Desbrosses, G., Bouffaud, M. L., Touraine, B., Moënne-Loccoz, Y., Muller, D., et al. (2013). Plant growth-promoting rhizobacteria and root system functioning. Front. Plant Sci. 4:356. doi: 10.3389/fpls.2013.00356

Valverde, A., Burgos, A., Fiscella, T., Rivas, R., Velazquez, E., Rodriguez-Barrueco, C., et al. (2007). "Differential effects of coinoculations with Pseudomonas jessenii PS06 (a phosphate-solubilizing bacterium) and Mesorhizobium ciceri C-2/2 strains on the growth and seed yield of chickpea under greenhouse and field conditions," in First International Meeting on Microbial Phosphate Solubilization. Developments in Plant and Soil Sciences, Vol. 102, eds E. Velázquez and C. Rodríguez-Barrueco (Dordrecht: Springer), 111-115.

Van Gerven, L. P. A., Kuiper, J. J., Mooij, W. M., Janse, J. H., Paerl, H. W., and De Klein, J. J. M. (2019). Nitrogen fixation does not axiomatically lead to phosphorus limitation in aquatic ecosystems. Oikos 128, 563-570. doi: 10.1111/oik.05246

Van Noorden, G. E., Ross, J. J., Reid, J. B., Rolfe, B. G., and Mathesius, U. (2006). Defective long-distance auxin transport regulation in the Medicago truncatula super numeric nodules mutant 1[W]. Plant Physiol. 140, 1494-1506. doi: 10.1104/pp.105.075879

Vanlauwe, B., Hungria, M., Kanampiu, F., and Giller, K. E. (2019). The role of legumes in the sustainable intensification of African smallholder agriculture: Lessons learnt and challenges for the future. Agric. Ecosyst. Environ. 284:106583. doi: 10.1016/j.agee.2019.106583

Vardien, W., Valentine, A. J., Mesjasz-Przybyłowicz, J., Przybyłowicz, W. J., Wang, Y., and Steenkamp, E. T. (2014). Nodules from Fynbos legume Virgilia divaricata have high functional plasticity under variable P supply levels. J. Plant Physiol. 171, 1732-1739. doi: 10.1016/j.jplph.2014.08.005

Verma, J. P., Yadav, J., and Tiwari, K. N. (2012). Enhancement of nodulation and yield of Chickpea by co-inoculation of indigenous Mesorhizobium spp. and plant growth-promoting Rhizobacteria in Eastern Uttar Pradesh. Commun. Soil Sci. Plant Anal. 43:3, 605-621, doi: 10.1080/00103624.2012.639110

Verma, J. P., Yadav, J., Tiwari, K. N., and Kumar, A. (2013). Effect of indigenous Mesorhizobium spp. and plant growth promotingrhizobacteria on yields and 
nutrients uptake of chickpea (Cicer arietinum L.) under sustainable agriculture. Ecol. Eng. 51, 282-286. doi: 10.1016/j.ecoleng.2012.12.022

Wagg, C., Bender, S. F., Widmer, F., and Van Der Heijden, M. G. A. (2014). Soil biodiversity and soil community composition determine ecosystem multifunctionality. Proc. Natl. Acad. Sci. U.S.A. 111, 5266-5270. doi: 10.1073/pnas.13200 54111

Wani, P. A., Khan, M. S., and Zaidi, A. (2007). Synergistic effects of the inoculation with nitrogen-fixing and phosphate-solubilizing rhizobacteria on the performance of field-grown chickpea. J. Plant Nutr. Soil Sci. 170, 283-287. doi: 10.1002/jpln.200620602

Xavier, L. J. C., and Germida, J. J. (2003). Selective interactions between arbuscular mycorrhizal fungi and Rhizobium leguminosarum bv. viceae enhance pea yield and nutrition. Biol. Fertil. Soils 37, 261-267. doi: 10.1007/s00374-003-0605-6

Yasmeen, S., and Bano, A. (2014). Combined effect of phosphate-solubilizing microorganisms, Rhizobium and Enterobacter on root nodulation and physiology of soybean (Glycine max L.). Commun. Soil Sci. Plant Anal. 45, 2373-2384. doi: 10.1080/00103624.2014.939192

Zaidi, A., Ahemad, M., Oves,., M., Ahmad, E., and Saghir, K. M. (2010). "Role of phosphate-solubilizing bacteria in legume improvement," in Microbes for
Legume Improvement, eds. Khan, A. Zaidi and J. Musarrat (Vienna: Springer) 273-292. doi: 10.1007/978-3-211-99753-6_11

Zaidi, A., and Khan, M. S. (2007). Stimulatory effects of dual inoculation with phosphate solubilising microorganisms and arbuscular mycorrhizal fungus on chickpea. Aust. J. Exp. Agric. 47, 1016-1022. doi: 10.1071/EA06046

Zaidi, A., Khan, M. S., Ahemad, M., Oves, M., and Wani, P. A. (2009). Recent advances in plant growth promotionby phosphate-solubilizing microbes. Microbial. Strat. Crop Improv. 23-50. doi: 10.1007/978-3-642-01979-1_2

Conflict of Interest: The authors declare that the research was conducted in the absence of any commercial or financial relationships that could be construed as a potential conflict of interest.

Copyright (๑ 2021 Janati, Benmrid, Elhaissoufi, Zeroual, Nasielski and Bargaz. This is an open-access article distributed under the terms of the Creative Commons Attribution License (CC BY). The use, distribution or reproduction in other forums is permitted, provided the original author(s) and the copyright owner(s) are credited and that the original publication in this journal is cited, in accordance with accepted academic practice. No use, distribution or reproduction is permitted which does not comply with these terms. 